\title{
DETERMINAN TOTAL FACTOR PRODUCTIVITY GROWTH SEKTOR PERTANIAN DI KAWASAN BARAT INDONESIA PERIODE 2013-2017 MENGGUNAKAN ANALISIS REGRESI DATA PANEL
}

\author{
(Determinant of Total Factor Productivity Growth of Agricultural Sector in Western \\ Indonesia Period 2013-2017 Using Panel Data Regression Analysis)
}

\author{
Revina Ayu Dya ${ }^{1}$, Budyanra ${ }^{2}$ \\ Politeknik Statistika STIS ${ }^{1}$ \\ Politeknik Statistika STIS 2 \\ Jl. Otto Iskandardinata No. 64C, Jakarta - 13330 \\ E-mail: 15.8846@stis.ac.id
}

\begin{abstract}
ABSTRAK
Sektor pertanian memiliki produktivitas terendah kedua dari tahun 2013-2017 dibandingkan sektor lain. Rendahnya nilai produktivitas sektor pertanian akan berdampak buruk terhadap perekonomian Indonesia dilihat dari pentingnya sektor ini. Jika ditinjau berdasarkan provinsi, sektor pertanian di Indonesia didominasi oleh provinsi yang berada di Kawasan Barat Indonesia (KBI). Akan tetapi, laju pertumbuhan PDRB pertanian di KBI selalu lebih rendah dibandingkan Kawasan Timur Indonesia (KTI), bahkan dari tahun 2013-2017 mengalami penurunun. Rendahnya laju pertumbuhan ekonomi disebabkan oleh rendahnya kemajuan teknologi. Peran kemajuan teknologi dalam proses produksi dapat dihitung menggunakan Total Factor Productivity (TFP). Oleh karena itu, penelitian ini bertujuan untuk menghitung TFP sektor pertanian di KBI, mengetahui gambaran umum TFP dan pertumbuhan TFP pertanian di KBI, dan menganalisis determinannya agar dapat diambil kebijakan yang tepat dalam meningkatkan produktivitas sektor pertanian. Pehitungan TFP pertanian menggunakan fungsi produksi Cobb-Douglas dengan metode estimasi FGLS-SUR dan hasilnya pertumbuhan TFP pertanian provinsi di Indonesia masih relatif rendah. Analisis variabel yang memengaruhi pertumbuhan TFP pertanian menggunakan regresi data panel dengan model fixed effect dan metode estimasi WLS. Diperolah bahwa pengeluaran litbang pertanian, dan bantuan alsintan secara positif signifikan memengaruhi pertumbuhan TFP serta inflasi pedesaan secara negatif signifikan memengaruhi pertumbuhan TFP.
\end{abstract}

Kata kunci: TFP, pertanian, analisis data panel

\section{ABSTRACT}

The Agricultural sectors have the second lowest productivity in 2013-2017 compared to other sectors. The low productivity value of the agricultural sector will adversely affect the Indonesian economy in terms of the importance of this sector. If reviewed by province, the agricultural sector in Indonesia is dominated by provinces in the Western Region of Indonesia (KBI). However, the growth rate of agricultural GRDP in KBI has always been lower than that of Eastern Indonesia (KTI), even from 2013-2017 experienced a decline. The low rate of economic growth is caused by low technological progress. The role of technological progress in the production process can be calculated using the Total Factor Productivity (TFP). Therefore this study aims to calculate the TFP of the agricultural sector in KBI, determine the general explanation of agricultural TFP in Indonesia, and analyze its determinants so that appropriate policies can be taken in increasing agricultural TFP. To calculate TFP uses a Cobb Douglas production function with FGLS-SUR estimation and the result is that provincial agricultural TFP growth is still relatively low. To find out the variables that affect agricultural TFP growth using the panel data regression with fixed effect model and WLS estimation. The result is agricultural RnD expenditure, and machineries grant significant and positif affect the growth of agricultural TFP in KBI, and rural inflation negatively significantly affects TFP growth.

Keywords: TFP, agriculture, panel data analyst

\section{PENDAHULUAN}

Negara dengan penduduk terbanyak ke-4 di dunia ini (Worldometers) adalah negara agraris, sektor pertanian merupakan sektor penting dalam perekonomian Indonesia. Hal ini karena sebagian besar penduduk Indonesia tinggal di daerah pedesaan dan menggantungkan kehidupannya pada sektor pertanian. Jumlah tenaga kerja sektor pertanian pada tahun 2017 adalah 35,9 juta orang 
Determinan Total Factor Productivity Growth Sektor Pertanian Di Kawasan Barat Indonesia Periode 2013-2017 Menggunakan Analisis Regresi Data Panel..

dengan kontribusi 29,69 persen dari total penduduk usia kerja di Indonesia. Selain itu sektor pertanian adalah sektor penyumbang terbesar kedua terhadap perekonomian Indonesia setelah industri pengolahan. Nilai PDB ADHB tahun 2017 sektor pertanian sebesar Rp 1.787.285,2 milyar dengan kontribusi 13,15 persen, sedangkan industri pengolahan sebesar Rp 2.739.711,9 milyar dengan kontribusi 20,16 persen.

Kontribusi yang besar dan jumlah tenaga kerja yang banyak di sektor pertanian Indonesia tidak diikuti oleh produktivitasnya. Dibandingkan dengan sektor lain sektor pertanian memiliki produktivitas yang rendah bersama dua sektor lainnya, yaitu sektor pengadaan air, pengelolaan sampah, limbah dan daur ulang dan sektor jasa lainnya. Pada tahun 2017 produktivitas sektor pertanian hanya Rp 35,01 juta per orang, sektor jasa lainnnya Rp 28,37 juta per orang dan sektor pengadaan air Rp 19,26 juta per orang. Sedangkan sektor yang paling produktif adalah sektor real estate, Rp 949 juta per orang dan sektor penyumbang terbesar terhadap PDB, sektor industri pengolahan produktivitasnya adalah Rp 119,8 juta per orang.

Rendahnya nilai produktivitas sektor pertanian akan berdampak buruk terhadap perekonomian Indonesia dilihat dari pentingnya sektor ini. Produktivitas yang rendah lambat laun akan menurunkan produksi. Disisi lain kebutuhan akan produksi pertanian tidak menurun karena jumlah penduduk yang selalu bertambah, sedangkan luas lahan cenderung konstan. Hal ini sesuai dengan teori jebakan Malthus (Todaro, 2003), bahwa penduduk bertambah mengikuti deret ukur sedangkan sumber daya pangan bertambah mengikuti deret hitung. Teori ini akan dapat dibantah dengan perkembangan teknologi. Maka untuk mengantisipasi hal tersebut perlu ditingkatkan penggunaan teknologi pada pertanian atau modernisasi pertanian guna meningkatkan produktivitas sektor pertanian.

Jika ditinjau berdasarkan provinsi, menurut data BPS pertanian Indonesia didominasi oleh provinsi-provinsi yang berada di Kawasan Barat Indonesia (KBI). Dari sisi PDRB, enam provinsi dengan kontribusi terbesar terhadap PDB pertanian adalah provinsi yang berada di KBI. Tidak hanya dari sisi PDRB tetapi juga dari sisi tenaga kerja pertanian, KBI lebih dominan dibanding Kawasan Timur Indonesia (KTI). Jumlah tenaga kerja pertanian di KBI mencapai dua kali lipat jumlah tenaga kerja pertanian di KTI.

Akan tetapi, pertumbuhan PDRB pertanian di KBI dari tahun 2012-2017 selalu lebih rendah dari pertumbuhan PDRB pertanian di KTI. Bahkan dari tahun 2013 pertumbuhan PDRB pertanian di KBI mengalami penurunan. Hal ini sangat disayangkan, karena seharusnya pertumbuhan PDRB pertanian KBI dapat mendorong pertumbuhan pertanian nasional. Rendahnya nilai pertumbuhan PDRB pertanian mungkin disebabkan oleh rendahnya perkembangan kemajuan teknologi. Asumsi ini didasari dari teori Solow mengatakan bahwa sumber pertumbuhan ekonomi ada tiga yaitu modal fisik, modal manusia dan kemajuan teknologi (Mankiw, 2006).

Rendahnya kemajuan teknologi dapat menyebabkan rendahnya produktivitas (Todaro, 2003). Produktivitas yang rendah akan menjadi berbahaya karena faktor input dari pertanian yang terus menurun. Hal ini ditandai dengan berkurangnya luas lahan pertanian akibat dari alih fungsi lahan yang digunakan untuk pemukiman serta beralihnya tenaga kerja pertanian ke sektor lain karena dirasa kurang menjanjikan.

Jika berkurangnya faktor input tidak diimbangi dengan peningkatan produktivitas maka akan terjadi kelangkaan bahan makanan. Maka untuk mengantisipasi kelangkaan bahan makanan seperti yang diprediksikan oleh Malthus, perlu adanya peningkatan pemanfaatan teknologi di sektor pertanian Indonesia. Peningkatan teknologi di sektor pertanian diharapkan dapat meningkatkan produktivitas.

Ukuran produktivitas yang dapat menggambarkan pengaruh penggunaan teknologi dalam proses produksi adalah Total Factor Productivity (TFP). TFP adalah ukuran dari produktivitas yang komprehensif, karena mampu mampu menjelaskan perubahan dalam produksi yang disebabkan oleh perubahan dalam jumlah input yang digunakan, perubahan dalam teknologi, dan pemanfaatan kapasitas dan kualitas faktor produksi (Darmawan, 2016). Selain itu TFP juga merupakan ciri proses pertumbuhan negara maju menurut Profesor S.S. Kuznet (Todaro, 2003). Oleh karena itu perumusan masalah pada penelitian ini adalah : (1) Bagaimana menghitung TFP pertanian di KBI, (2) Bagaimana gambaran umum TFP dan pertumbuhan TFP pertanian di KBI dan (3) Apa saja variabel yang memengaruhi pertumbuhan TFP di Indonesia? Dengan rumusan masalah tersebut, 
tujuan dari penelitian ini adalah : (1) Menghitung TFP pertanian di KBI, (2) Mengetahui gambaran umum TFP dan pertumbuhan TFP pertanian di KBI dan (3) Menganalisis variabel-variabel yang memengaruhi pertumbuhan TFP.

Penelitian tentang TFP telah dilakukan oleh Evenson (1973) di India pada tahun 1953-1971. Peneliti fokus kepada meneliti pengaruh dari sistem penelitian pertanian terhadap produksi pertanian dan hasilnya adalah positif. Terbukti bahwa keberhasilan produksi pertanian selama periode penelitian adalah dampak dari sistem tersebut.

\section{METODE}

\subsection{Kajian Teori}

\section{Produktivitas}

Produktivitas adalah rasio dari output yang dihasilkan dengan input yang digunakan. Pengukuran produktivitas dapat dilakukan secara parsial dan secara total. Pengukuran produktivitas parsial contohnya adalah produktivitas tenaga kerja pada perusahaan dan produktivitas lahan pada pertanian. Ukuran produktivitas parsial ini dapat menghasilkan indikasi yang salah terhadap produktivitas secara keseluruhan. Sedangkan produktivitas total atau Total Factor Productivity (TFP) adalah ukuran produtivitas yang melibatkan semua output dan input dalam pengukurannya (Coelli, 2005). TFP juga dapat diartikan sebagai bagian dari output yang tidak bisa dijelaskan oleh input konvensionalnya (Comin, 2006).

Landasan teori pertumbuhan ekonomi yang digunakan banyak mengacu pada model pertumbuhan neo-klasik dimana tingkat pertumbuhan suatu negara hanya dijelaskan dengan penekanan kepada fungsi produksi agregat dengan faktor produksi tenaga kerja dan kapital. Faktor lain yang memengaruhi pertumbuhan ekonomi selain tenaga kerja dan kapital dianggap sebagai kemajuan teknologi yang bersifat eksogen (Solow dalam Mankiw, 2003). Menurut Solow Model yang digunakan untuk mengukur TFP berasal dari fungsi produksi Cobb Douglas.

Romer pada tahun 1986 mengembangkan teori pertumbuhan endogen yang dapat mengatasi beberapa permasalahan yang pada teori pertumbuhan neo-klasik, salah satunya adalah menghilangkan asumsi eksogen daru kemajuan teknologi. Meskipun ada perbedaan asumsi, fungsi produksi yang digunakan sama dengan yang diajukan oleh Robet M, Solow.

Van Beveran (2010) menggunakan data panel untuk menghitung TFP dengan menambahkan satu variabel input lagi yaitu material $(\mathrm{M})$, sehingga fungsi produksi yang digunakan terdiri dari tiga input yaitu tenaga kerja (L), kapital $(\mathrm{K})$ dan material $(\mathrm{M})$. Berdasarkan linearisasi fungsi produksi Cobb Douglas, In TFP dapat dihasilkan dari In output dikurangi dengan hasil perkalian share masingmasing input dengan In inputnya.

$$
\left.\ln \widehat{(T F P}_{l t}\right)=\ln Y_{i t}-\hat{\beta}_{k} \ln K_{i t}-\hat{\beta}_{l} \ln L_{i t}-\hat{\beta}_{m} \ln M_{i t}
$$

$\ln \left(\widehat{T F P}_{l t}\right) \quad$ : logaritama natural TFP individu ke-i tahun ke-t

$\ln Y_{i t} \quad$ : logaritama natural ouput individui ke-i tahun ke-t

$\ln K_{i t} \quad$ : logaritama natural input kapital individu ke-i tahun ke-t

$\ln L_{i t} \quad$ : logaritama natural input tenaga kerja individu ke-i tahun ke-t

$\ln _{i t} \quad$ : logaritama natural input material individui ke-i tahun ke-t

$\beta \quad$ : parameter masing-masing input

i $\quad$ : individu ; $\mathrm{i}=1,2, \ldots \mathrm{N}$

t $\quad$ : tahun

\section{Faktor-Faktor Yang Memengaruhi Produktivitas}

Solomon Fabricant dalam John W.Kendrick (1961) mengatakan bahwa peningkatan dalam output nasional per jam adalah hasil dari beberapa faktor. Faktor pertama adalah investasi besar dalam bisnis dan pabrik dan peralatan pertanian, dalam perbaikan publik, dan pada barang modal nyata lainnya. Faktor kedua, adalah investasi dalam pendidikan dan pelatihan di tempat kerja dan dari pengeluaran untuk penelitian dan pengembangan dan bentuk-bentuk lain dari modal tak berwujud. Faktor ketiga adalah peningkatan efisiensi yang sangat besar dalam penggunaan tenaga kerja negara dan sumber daya modal yang berwujud dan tidak berwujud. 
Namboodiri (1997) dalam penelitiannya mengatakan bahwa TFP dipengaruhi oleh dua faktor yaitu price factors and non price factors. Price factor didekati dengan variabel BTOT (Barter Trade of Trade) atau rasio antara harga yang diterima petani dan harga yang dibayar. Peran insentif harga sudah jelas efektif dalam mendorong perubahan teknis. Non Price Factor adalah faktor yang akan menyebabkan perubahan struktural pada pertanian. Perubahan ini dapat berupa perubahan dari pertanian kuno ke pertanian modern yang berbasis ilmu pengetahuan dan teknologi. Faktor ini dapat didekati dengan biaya penelitian dan pengembangan, rasio penggunaan pupuk, kanal irigasi, angka melek huruf, infrastruktur pemasaran dan perbankan, dan lain-lain.

\section{Analisis Regresi}

Analisis regresi adalah metodologi statistik yang memanfaatkan hubungan antara dua atau lebih variabel kuantitatif sehingga variabel respons atau hasil dapat diprediksi dari variabel lain (Neter, 1983). Berdasarkan jenis data yang digunakan analisis regresi dapat dibedakan menjadi tiga, yaitu analisis regresi data cross section, analisis regresi data time series dan analsis regresi data panel (Gujarati, 2004). Analisis regresi data panel dapat dilakukan dengan tiga bentuk model, yaitu common effect model, fixed effect model dan random effect model (Gujarati,2004).

\subsection{Ruang Lingkup Penelitian}

Penilitian ini bertujuan untuk menghitung besarnya TFP sektor pertanian di KBI, mengetahui gambaran umum TFP dan pertumbuhan TFP pertanian di KBI, dan menganalisis determinannya. Penelitian ini menggunakan data panel dengan cross section 16 provinsi dengan mengeluarkan Provinsi DKI Jakarta karena bukan provinsi dominan sektor pertanian, serta periode 5 tahun dari tahun 2013 hingga tahun 2017. Variabel dependen yang digunakan adalah pertumbuhan TFP pertanian yang merupakan hasil perhitungan. Variabel independen yang digunakan adalah pengeluaran pemerintah untuk penelitian dan pengembangan di bidang pertanian, bantuan alat dan mesin pertanian (alsintan), inflasi perdesaan, dan Nilai Tukar Petani.

\subsection{Metode Pengumpulan Data}

Data yang digunakan adalah data sekunder yang diperoleh dari Badan Pusat Statistik, Kementerian Pertanian, Kementdan Badan Penelitian dan Pengembangan Pertanian. Berikut rincian sumber data yang digunakan dalam penelitian ini :

1. Nilai PDRB ADHK sektor pertanian diperoleh dari tabel dinamis PDRB ADHK menurut lapangan usaha tahun 2013-2017 melalui website BPS masing-masing provinsi. Penelitian ini menggunakan PDRB dengan kode klasifikasi lapangan usaha satu, yaitu Pertanian, Kehutanan dan Perikanan atas dasar harga konstan tahun dasar 2010.

2. Jumlah tenaga kerja pertanian diperoleh dari publikasi Keadaan Angkatan Kerja di Indonesia yang dirilis oleh BPS dua kali setahun, bulan Februari dan bulan Agustus. Data dalam penelitian ini menggunakan publikasi yang dirilis pada bulan Agustus dari tahun 2013-2017. Tenga kerja pertanian adalah penduduk berusia 15 tahun ke atas yang bekerja selama seminggu yang lalu menurut provinsi dan lapangan pekerjaan utama pertanian, kehutanan, perburuan dan perikanan.

3. Luas lahan pertanian yang digunakan adalah luas sawah, kebun, ladang, areal budidaya perikanan dan areal perusahaan hak pengusahaan hutan. Data luas sawah, kebun dan ladang diperoleh dari Statistik Luas Lahan Pertanian tahun 2013-2017 yang dikeluarkan oleh Kementerian Pertanian. Luas areal budidaya perikanan diperoleh dari website BPS pada bagian tabel perikanan yang dihitung oleh Kementerian Kelautan dan Perikanan. Luas areal perusahaan hak pengusahaan hutan dari website BPS pada bagian tabel kehutanan.

4. Pertumbuahan TFP adalah hasil perhitungan menggunakan analisis regresi data panel. Model yang digunakan adalah:

$$
\ln P R D B P_{i t}=\alpha+\beta_{1} \operatorname{lnTKP} P_{i t}+\beta_{2} \ln \operatorname{Lahan} P_{i t}+\beta_{3} \operatorname{lnIBP} P_{i t}+u_{i t}
$$

TFP dihitung dengan memanfaatkan nilai koefisien masing-masing variabel menggunakan rumus berikut :

$$
\begin{gathered}
\operatorname{lnTFP}=\alpha+u_{i t}=\ln P D R B_{i t}-\hat{\beta}_{1} \ln T K P_{i t}-\hat{\beta}_{2} \ln \operatorname{Lahan} P_{i t}-\hat{\beta}_{3} \ln I B P_{t} \\
T F P=e^{\ln F P}
\end{gathered}
$$


Dari nilai TFP yg diperoleh, dihitung invers logaritma naturalnya sebagai nilai TFP. Selanjutnya dihitung pertumbuhan TFP (GTFP) untuk setiap provinsi dengan rumus :

$$
G T F P_{i t}=\frac{T F P_{i t}-T F P_{i t-1}}{T F P_{i t-1}} \times 100
$$

Proses perhitungan terdapat pada lampiran 1.

5. Bantuan alat dan mesin pertanian didapat dari publikasi Statistik Sarana Pertanian tahun 20132017.

6. Indeks biaya produksi pertanian didapat dari Statistik Nilai Tukar Petani dari tahun 2013-2017 yang dihasilkan oleh Badan Pusat Statistik. Indeks biaya produksi pertanian adalah indeks harga yang menunjukkan perkembangan harga biaya produksi dan penambahan barang modal terdiri dari biaya bibit; pupuk, obat-obatan, dan pakan; biaya sewa dan pengeluaran lainnya; transportasi; barang modal dan upah buruh tani.

7. Pengeluaran pemerintah untuk penelitian dan pengembangan pertanian berasal dari publikasi Statistik Penelitian dan Pengembangan Pertanian 2013-2017 yang dikeluarkan oleh Badan Penelitian dan Pengembangan Pertanian. Pengeluaran pemerintah untuk penelitian dan pengembangan pertanian adalah anggaran Balai Pengkajian Teknologi Pertanian setiap provinsi untuk Rencana Penelitian/Pengkajian Tim Peneliti/Pengkaji (RPTP) dan Rencana Diseminasi Hasil Penelitian/Pengkajian (RDHP).

8. Nilai Tukar Petani diperoleh dari publikasi Statistik Nilai Tukar Petani dari tahun 2013-2017 yang dihasilkan oleh Badan Pusat Statistik. Nilai Tukar Petani adalah angka perbandingan antara indeks harga yang diterima petani dengan indeks harga yang dibayar petani yang dinyatakan dalam persentase.

9. Inflasi perdesaan berasal dari perhitungan menggunakan indeks konsumsi rumah tangga petani dari publikasi Statistik Nilai Tukar Petani dari tahun 2013-2017 yang dihasilkan oleh Badan Pusat Statistik.

\subsection{Metode Analisis}

Analisis yang dilakukan dapat dikategorikan menjadi dua yaitu analisis deskriptif dan analisis inferensia. Analisis deskriptif dilakukan untuk mengetahui gambaran umum TFP dan pertumbuhan TFP pertanian di KBI pada tahun 2013-2017. Analisis yang dilakukan berupa, grafik dan peta tematik. Sedangkan analisis inferensia dilakukan untuk menganalisis variabel-variabel yang memengaruhi pertumbuhan TFP pertanian level provinsi di Indonesia pada tahun 2014-2017. Analisis inferensia dilakukan dengan analisis regresi data panel. Adapun tahap-tahap untuk melakukan analisis inferensia tersebut adalah sebagai berikut :

1. Menyiapkan data yang diperlukan dari sumber terkait.

2. Melakukan perhitungan pertumbuhan TFP menggunakan rumus (2) hingga (5).

3. Pemilihan model terbaik. Dimulai dari uji chow untuk memilih model terbaik antara model common effect dan model fixed effect. apabila yang terpilih adalah comman effect dilanjutkan dengan uji BP-LM untuk memilih model terbaik antara comman effect dan random effect. Jika yang terpilih pada uji chow adalah model fixed effect, maka dilanjutkan dengan uji Hausman untuk memilih model terbaik antara model fixed effect dan random effect.

4. Pengujian struktur matriks varians kovarians residual. Pengujian dilakukan dengan uji LM untuk melihat apakah matriks varians kovarians residual bersifat homoskedastik atau heteroskedastik. Jika hasilnya menunjukkan bahwa terdapat gejala heteroskedastik maka dilanjutkan dengan uji untuk menguji ada atawatidaknya cross-sectional correlation.

5. Pemilihan metode estimasi sesuai dengan struktur matriks varians kovarians residual dan ada atau tidaknya cross-sectional correlation residual.

6. Pemeriksaan asumsi klasik dilakukan sesuai dengan metode estimasi yang digunakan. Jika menggunakan metode OLS maka asumsi klasik yang harus dipenuhi adalah : normalitas, nonmultikolinearitas, homoskedastisitas dan nonautokorelasi. Tetapi jika metode estimasi menggunakan selain OLS, seperti GLS, FGLS, WLS dll maka asumsi klasik yang harus dipenuhi hanya dua, yaitu normalitas dan nonmultikolinearitas.

7. Melakukan pengujian keberartian model dengan menggunakan koefisien determinasi $\left(R^{2}\right)$, uji simultan $\mathrm{F}$, dan uji parsial $\mathrm{t}$. 
8. Interpretasi hasil sesuai model yang digunakan.

Model yang digunakan untuk melakukan analisis variabel-variabel yang memengaruhi pertumbuhan TFP dilakukan analisis regresi data panel dengan model sebagai berikut :

Model common effect:

Model fixed effect.

$$
T F P G_{i t}=\alpha+\beta_{1} \text { Litbang }_{i t}+\beta_{2} \text { Alsintan }_{i t}+\beta_{3} \text { InflasiDesa }_{i t}+\beta_{4} N T P_{i t}+v_{i t}
$$

Model random effect:

$$
T F P G_{i t}=\left(\alpha+\mu_{i}\right)+\beta_{1} \text { Litbang }_{i t}+\beta_{2} \text { Alsintan }_{i t}+\beta_{3} \text { InflasiDesa }_{i t}+\beta_{4} \text { NTP }_{i t}+v_{i t}
$$

$$
\text { TFPG }_{i t}=\alpha+\beta_{1} \text { Litbang }_{i t}+\beta_{2} \text { Alsintan }_{i t}+\beta_{3} \text { InflasiDesa }_{i t}+\beta_{4} N T P_{i t}+\left(v_{i t}+\mu_{i}\right)
$$

Keterangan :

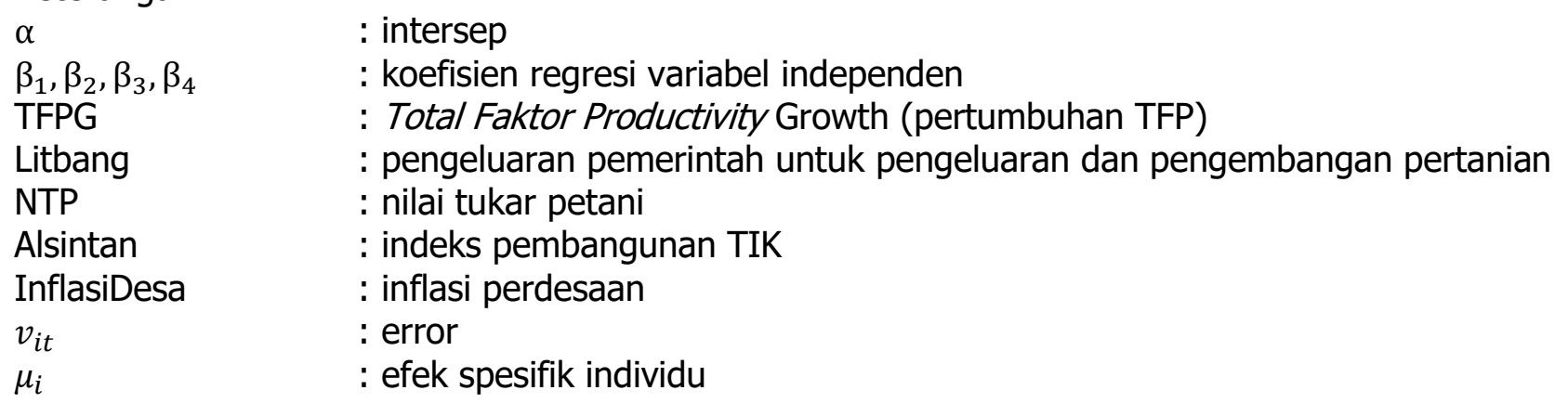

\section{HASIL DAN PEMBAHASAN}

\subsection{Perhitungan TFP Pertanian}

Setelah melakukan pemilihan model terbaik, pengujian struktur matriks varians kovarians residual, pemilihan metode estimasi dan pengujian asumsi klasik, model terbaik yang digunakan dalam melakukan perhitungan TFP adalah fixed effect dengan struktur matriks varian kovarian heteroskedastis dan tidak terdapat cross sectional correlation, sehingga metode estimasi yang digunakan adalah WLS. Model yang digunakan telah memenuhi asumsi klasik sehingga persamaan yang didapat adalah :

$$
\ln \widehat{P D R B}_{i t}=\left(6,7708+\hat{\mu}_{i}\right)-0,1218{\ln \operatorname{Lahan}^{*}}_{i t}+0,8400 \operatorname{lnIB}^{*}{ }_{i t}+0,0979 \ln T K^{*}{ }_{i t}
$$

Dari persamaan ini dihitunglah nilai TFP menggunakan rumus (2) hingga (5). Contoh perhitungan TFP untuk Provinsi Aceh tahun 2013 dan tahun 2014. Data yang dibutuhkan adalah :

Tabel 1. Data yang digunakan untuk menghitung TFP Aceh tahun 2013-2014

$\begin{array}{ccccc}\text { Tahun } & \text { Ln PDRB } & \text { Ln Lahan } & \text { Ln TK } & \text { LnIB } \\ (1) & (2) & (3) & (4) & (5) \\ 2013 & 10,2744 & 13,9395 & 13,6517 & 4,5853 \\ 2014 & 10,2986 & 13,8957 & 13,6551 & 4,6648\end{array}$

Dari persamaan (3), dimasukkan nilai pada tabel 1 dan estimasi parameter pada persamaan (9), sehingga:

TFP Aceh Tahun 2013 adalah :

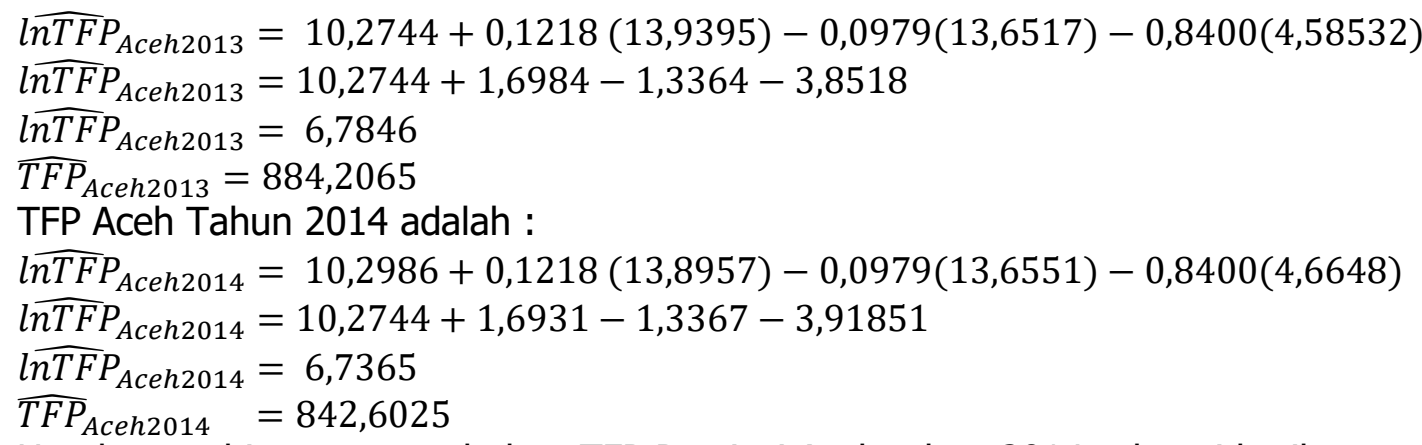

Untuk menghitung pertumbuhan TFP Provinsi Aceh tahun 2014 sebagai berikut :

$G T F P_{\text {Aceh } 2014}=\frac{T F P_{\text {Aceh } 2014}-T F P_{\text {Aceh } 2013}}{T F P_{\text {Aceh } 2013}} \times 100$ 
$\begin{aligned} G T F P_{\text {Aceh } 2014} & =\frac{842,6025-884,2065}{884,2065} \times 100 \\ G T F P_{\text {Aceh } 2014} & =-4.7052\end{aligned}$

Perhitungan TFP dilakukan seperti di atas untuk setiap provinsi dari tahun 2013-2017.

\subsection{Gambaran Umum TFP dan Pertumbuhan TFP Pertanian Provinsi di Indonesia tahun 2017}

Hasil perhitungan TFP adalah suatu nilai yang tidak bisa diinterpretasikan secara parsial, hanya bisa dibandingkan dengan nilai lainnya. Gambar 1 adalah hasil perhitungan TFP pada tahun 20132017. Pada Gambar 1 terlihat bahwa TFP pertanian di Kawasan Barat Indonesia pada lima tahun terakhir tidak mengalami perubahan yang signifikan. Provinsi yang mengalami kenaikan TFP pertanian selama periode 2013-2017 adalah provinsi Sumatera Utara, Provinsi Riau, dan Provinsi Jambi. Provinsi dengan nilai TFP tertinggi pada tahun 2017 adalah Provinsi Jawa Timur sedangkan provinsi dengan nilai TFP terendah adalah Provinsi Kepualauan Riau. Lebih tingginya nilai TFP pertanian di Provinsi Jawa Timur dibanding Provinsi Kepeluaan Riau menandakan bahwa penggunaan teknologi dan penggunaan input berkualitas dalam proses produksi pertanian di Provinsi Jawa Timur lebih tinggi dan lebih baik dibanding Provinsi Kepulauan Riau.

Peningkatan produktivitas pertanian di KBI yang digambarkan dengan pertumbuhan TFP level provinsi di KBI pada tahun 2014-2017 sangat berfluktuatif. Hal ini menandakan bahwa peran teknologi dalam proses produksi pertanian belum stabil, belum menjadi prioritas utama. Secara ratarata pertumbuhan TFP pertanian pada tahun 2014-2017 disajikan pada gambar 2. Dapat dilihat bahwa rata-rata pertumbuhan TFP level provinsi di Kawasan Barat Indonesia bervariatif. Provinsi dengan rata-rata pertumbuhan TFP tertinggi adalah Provinsi Jambi dengan nilai 3,41 persen, sedangkan provinsi dengan rata-rata pertumbuhan TFP terendah adalah Provinsi Bengkulu dengan nilai $-2,63$ persen.

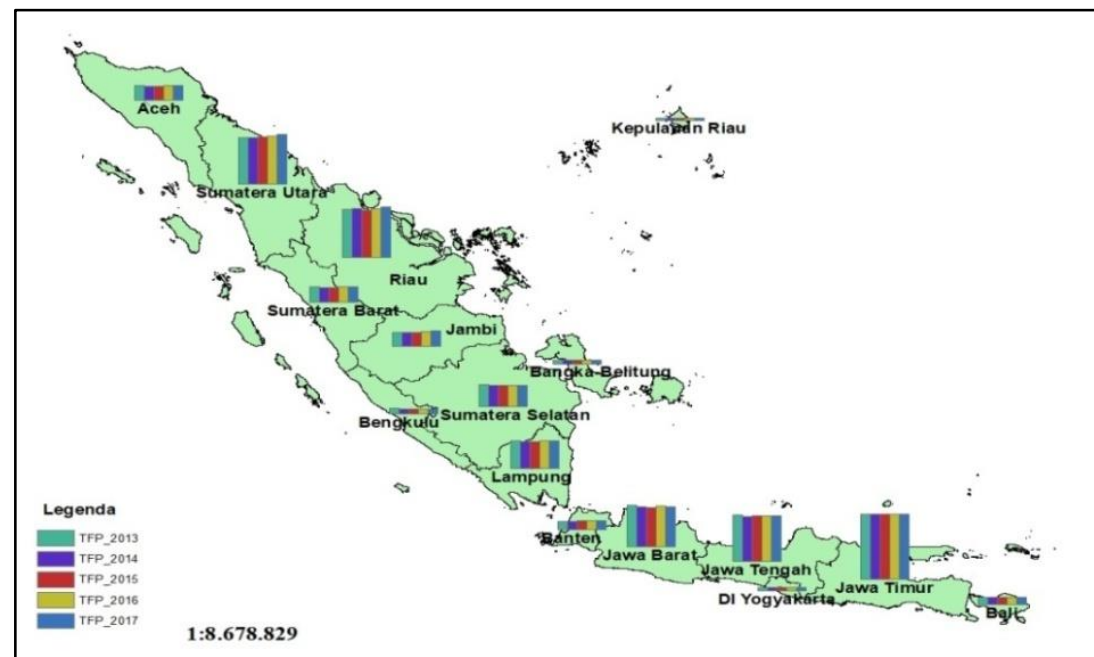

Gambar 1. Nilai Total Factor Productivity tahun 2013-2017.

Pertumbuhan TFP yang rendah menunjukkan bahwa peningkatan output pertanian di Kawasan Barat Indonesia selama periode penelitian masih bergantung kepada peningkatan jumlah input tenaga kerja, luas lahan dan bahan-bahan produksi dibandingkan dengan peningkatan kualitas dari masing-masing input atau kemajuan teknologi yang digunakan. Ketergantungan yang tinggi terhadap kuantitas dari faktor input akan berdampak buruk terhadap jumlah output apabila faktor input mengalami penurunan. 


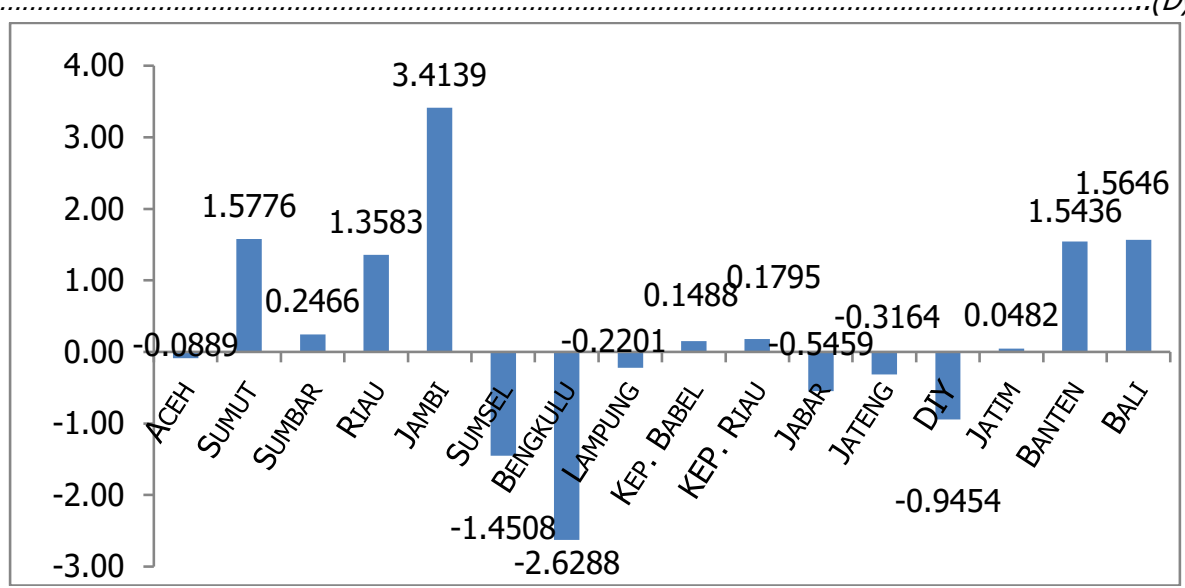

Gambar 2. Rata-rata pertumbuhan TFP pertanian tahun 2014-2017.

Gambar 3 adalah lima provinsi dengan PDRB pertanian terbesar di Kawasan Barat Indonesia selama periode penelitian tahun 2013-2017. Dari Gambar 3 terlihat bahwa dua dari lima provinsi tersebut memiliki pertumbuhan TFP yang negatif. Tiga provinsi lainnya memiliki pertumbuhan TFP yang masih rendah dibandingkan pertumbuhan PDRB. Hal ini menunjukkan bahwa tingginya peningkatan produksi pertanian di provinsi tersebut masih bergantung kepada peningkatan kuantitas input konvensional belum memanfaatkan peningkatan kualitas input dan kemajuan teknologi. Pertumbuhan PDRB pertanian pada dua provinsi di atas belum bersumber dari pertumbuhan TFP, tetapi dari pertumbuhan tenaga kerja, luas lahan dan bahan produksi yang digunakan. Pertumbuhan seperti ini akan sangat rawan untuk turun jika jumlah inputnya berkurang. Padahal fenomena yang terjadi saat ini adalah banyaknya perpindahan tenaga kerja dari sektor pertanian ke sektor non pertanian dan alih fungsi lahan pertanian ke non pertanian. Berbeda hal nya dengan provinsi yang telah bergantung kepada pertumbuhan TFP, berkurangnya jumlah input tidak akan terlalu memengaruhinya karena adanya peran kemajuan teknologi untuk mengimbangi.

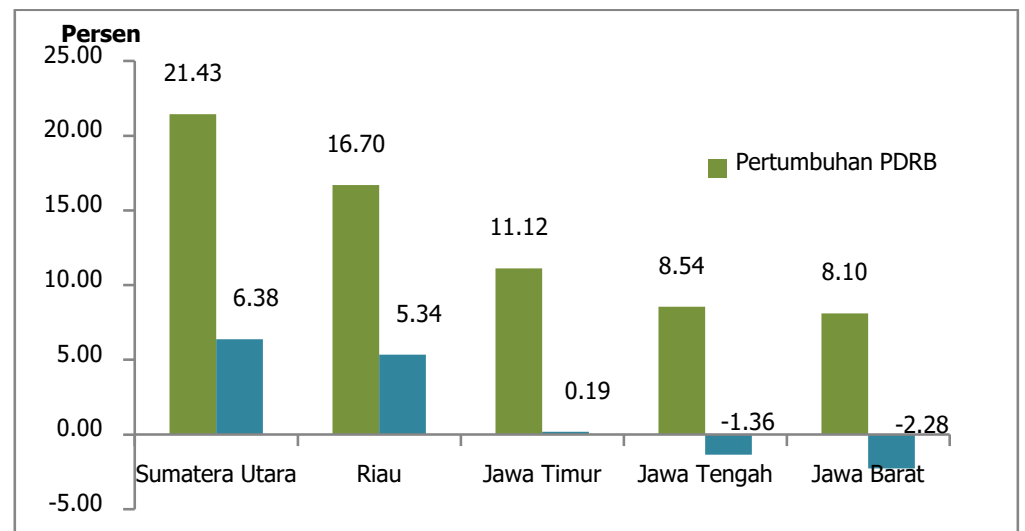

Gambar 3. Pertumbuhan PDRB pertanian dan pertumbuhan TFP pertanian pada lima provinsi dominan pertanian tahun 2017

\subsection{Analisis Variabel Yang Memengaruhi Pertumbuhan TFP Pertanian Provinsi di Indonesia Tahun 2014-2017}

Setelah melakukan pemilihan model terbaik, pengujian struktur matriks varians kovarians residual karena model terpilih adalah fixed effect, pemilihan metode estimasi dan pengujian asumsi klasik, model terbaik yang digunakan dalam analisis variabel yang memengaruhi pertumbuhan TFP adalah fixed effect dengan struktur matriks varian kovarian heteroskedastis dan tidak terdapat cross sectional correlation, sehingga metode estimasi yang digunakan adalah WLS. Ringkasan model pada tabel 2 di bawah ini :

Tabel 2. Ringkasan Model Regresi Variabel Yang Memengaruhi TFP tahun 2013-2017

\begin{tabular}{ccccc} 
Variabel & Koefisien & thitung $_{\text {na }}$ & $t_{(0,05 ; 4)}$ & $t_{(0,1 ; 44)}$ \\
$(1)$ & $(2)$ & $(3)$ & $(4)$ & $(5)$ \\
C & $-50,8214$ & $-3,1821$ & 2,0003 & 1,6802 \\
\hline
\end{tabular}




\begin{tabular}{ccccc}
\hline Ln_Litbang & 2,9432 & 4,7408 & 2,0003 & 1,6802 \\
Alsintan & 0,3429 & 1,7538 & 2,0003 & 1,6802 \\
InflasiDesa & $-0,3167$ & $-2,6687$ & $-2,0003$ & $-1,6802$ \\
NTP & 0,0585 & 0,5138 & 2,0003 & 1,6802 \\
\hline \multicolumn{5}{c}{ Ringkasan Statistik } \\
\hline \multicolumn{5}{c}{0,7318} \\
Adjusted R ${ }^{2}$ & 0,6160 \\
Fhitung & 6,3199 \\
F(0,05;(19,44)) & & 1,8281 & \\
\hline
\end{tabular}

Hasil regresi menunjukkan bahwa secara simultan variabel independen berpengaruh signifikan terhadap variabel dependen terlihat dari nilai $F_{\text {hitung }}$ yang lebih besar dari $F_{(0,05 ;(19,44)) \text {. Hasil uji parsial }}$ menunjukkan bahwa dua dari empat variabel signifikan pada signifikansi 5 persen dan tiga dari empat variabel independen berpengaruh signifikan terdapat variabel dependen pada tingkat

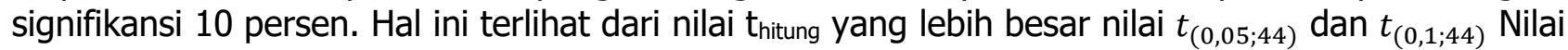
adjusted $\mathrm{R}^{2}$ sebesar 0,6160 menunjukkan bahwa 61,6 persen variabel pertumbuhan TFP dapat dijelaskan oleh variabel independen di atas.

Persamaan yang terbentuk dalam penilitian ini adalah :

$$
\begin{gathered}
\widehat{T F P G}_{i t}=\left(-50,8214+\mu_{i}\right)+2,9432 \text { Ln_Litbang }^{*}{ }_{i t}+0,3429 \text { Alsintan }^{* *}{ }_{i t}-0,3167 \text { InflasiDesa }^{*}{ }_{i t} \\
+0.0585 \text { NTP }_{i t}
\end{gathered}
$$

*) signifikan pada tingkat signifikansi 5 persen

**)signifikan pada tingkat signifikansi 10 persen

$T F P G_{i t} \quad$ : pertumbuhan TFP pertanian provinsi ke-i tahun ke-t

$\mu_{i}$

$L N_{-} L_{\text {Litbang }}$ : : logaritma natural penelitian dan pengembangan pertanian provinsi ke-i tahun ke $\mathrm{t}$

Alsintan $_{i t} \quad$ : bantuan alat dan mesin pertanian provinsi ke-i tahun ke-t

$N T P_{i t} \quad$ : nilai tukar petani provinsi ke-i tahun ke-t

InflasiDesa $a_{i t} \quad$ : inflasi ibu kota provinsi ke-i tahun ke-t

i : provinsi; $\mathrm{i}=1,2, \ldots, 16$

t $\quad:$ tahun ; $\mathrm{t}=2014,2015,2016,2017$

\section{Interpretasi Hasil}

Variabel pengeluaran pemerintah untuk penelitian dan pengembangan di bidang pertanian berpengaruh positif tehadap pertumbuhan TFP pertanian. Hal ini sesuai dengan penelitian yang dilakukan oleh Po-Chi Chen et.al, (2008) dan Namboodiri (1998). Semakin banyak dana yang dialokasikan oleh pemerintah untuk penelitian dan pengembangan akan meningkatkan kemungkinan pemanfaatan teknologi baru pada produksi pertanian yang akan meningkatkan produktivitas. Hasil yang diperoleh sesuai dengan hipotesis awal bahwa pengeluaran pemerintah untuk penelitian dan pengembangan di bidang pertanian berpengaruh positif terhadap pertumbuhan TFP pertanian. Setiap kenaikan pengeluaran pemerintah untuk penelitian dan pengembangan pertanian sebesar 1 persen akan meningkatkan pertumbuhan TFP pertanian sebesar 0,0294 persen dengan asumsi pengaruh variabel lain tetap.

Variabel bantuan alat dan mesin pertanian berpengaruh positif terhadap pertumbuhan TFP pertanian. Hasil ini sesuai dengan penemuan pada penelitian sebelumnya yang dilakukan oleh PoChi Chen et.al (1997), bahwa semakin luas lahan yang diolah menggunakan mesin akan semakin besar pertumbuhan TFP. Dengan asumsi semua bantuan alat dan mesin digunakan dengan efektif. Hasil penelitian sesuai dengan hipotesis awal bahwa bantuan alat dan mesin pertanian berpengaruh positif terhadap pertumbuhan TFP pertanian. Setiap bertambahnya bantuan alat dan mesin pertanian sebanyak 1000 alat ke suatu daerah akan meningkatkan pertumbuhan TFP pertanian sebesar 0,3429 persen dengan asumsi pengaruh variabel lain tetap.

Variabel inflasi perdesaan berpengaruh negatif terhadap pertumbuhan TFP pertanian. Hal ini menunjukkan bahwa naiknya inflasi perdesaan dapat menurunkan pertumbuhan TFP pertanian. Penemuan ini sesuai dengan penelitian yang dilakukan Ali (2012) di Pakistan, bahwa tingginya harga dan ketidakstabilan ekonomi menciptakan banyak ketidakpastian ekonomi sehingga menghambat investasi pada pertanian yang akan berdampak buruk terhadap pertumbuhan TFP. 
Determinan Total Factor Productivity Growth Sektor Pertanian Di Kawasan Barat Indonesia Periode 2013-2017 Menggunakan Analisis Regresi Data Panel..

Hasil penelitian sesuai dengan hipotesis awal bahwa inflasi perdesaan berpengaruh negatif terhadap pertumbuhan TFP pertanian. Setiap kenaikan inflasi perdesaan sebesar 1 satuan akan menurunkan pertumbuhan TFP pertanian sebesar 0,3167 persen dengan asumsi pengaruh variabel lain tetap.

Variabel Nilai Tukar Petani berpengaruh positif terhadap pertumbuhan TFP pertanian tetapi tidak signifikan. Tidak signifikannya variabel Nilai Tukar Petani disebabkan karena dampak positif dari peningkatan insentif bagi petani sebanding dengan dampak negatifnya melalui berkurangnya investasi kembali untuk proses pertanian tetapi malah digunakan untuk konsumsi sehingga menjadi tidak efisien (Namboodiri, 1998).

\section{KESIMPULAN}

Dari hasil penelitian ini dapat diambil kesimpulan bahwa lima provinsi dengan TFP pertanian tertinggi di KBI adalah Provinsi Jawa Timur, Provinsi Sumatera Utara, Provinsi Jawa Tengah, Provinsi Jawa Barat dan Prov insi Riau. Sedangkan pertumbuhan TFP pertanian di KBI relatif rendah pada tahun 2014-2017. Provinsi dengan rata-rata pertumbuhan TFP tertinggi pada tahun 2014-2017 adalah Provinsi Jambi dan yang terendah adalah Provinsi Bengkulu. Dari penelitian ini juga didapat variabel-variabel yang memengaruhi pertumbuhan TFP pertanian di KBI adalah pengeluaran untuk penelitian dan pengembangan pertanian, inflasi pedesaan, dan bantuan alat dan mesin pertanian.

\section{DAFTAR PUSTAKA}

\section{Artikel dalam Jurnal (Jurnal Primer)}

Chen, Po-chi.,Ming Miin Yu,Ching-Cheng Chang, \& Shin-Hsun Hsu.(2008). Total Factor Productivity Growth In China's Agriculturalsector. China economic Review 19 (2008),580-593

Comin, Diego.(2006). Total Factor Productivity.New York : New York University and NBER

Darmawan, Rizal Rahmat. (2016). Analasis Nilai Total FAktor Produktivitas pada Industri Manufaktur di Jawa Timur. Jurnal Ilmu Ekonomi Terapan Juni 2016; 01(1): 57-71

Desai, Bhupat M. \& Namboodiri, N. V. (1998). Determinants of Total Factor Producitivity in Indian Agricultural. Economic and Political Weekly, Vol. 32, No. 52.

Evenson, Robert.E \&Jha, Dayana. (1973). The Contribution Of Agricultural Research System To Agricultural Production In India. Indian journal of agricultural economics, Vol XXVIII No.4

Van, Beveran. (2010). Total Factor Productivity Estimation: A Practical Review. Journal of economic survey post.

\section{Buku}

Coelli, Timothy J., D.S.Prasada Rao, Christopher J. O'Donnell, \& George E. Battese. (2005). An Introduction to Efficiency and Productivity Analysis. Second Edition. United States of America : Springer

Science+Bussiness Media

Kendrick, John W. (1961). Productivity Trends In The United States. Princeton University Press : New Jersey Neter, John.(1983). Applied Linear Regression Models. United States of America: Richard D. Irwin Inc.

Todaro, Michael P. (2000). Pembangunan Ekonomi di Dunia Ketiga. Jakarta : Erlangga.

Todaro, M. P. \& S. C. Smith. (2003). Pembangunan Ekonomi di Dunia Ketiga. Jilid 1. Edisi Kedelapan. Jakarta: Erlangga.

\section{Naskah Online}

Worldometers, https://www.worldometers.info/world-population/ diakses pada 20 Juni 2019 